\title{
Deus, referência absoluta na mudança da cultura: como apresentar Deus hoje ${ }^{1}$
}

Camillo Ruini

\section{Resumo}

O autor aborda o tema de Deus e da possibilidade da fé no contexto cultural contemporâneo. Apesar de a história confirmar que a relação do homem com a religião e com Deus é uma constante nas diversas culturas, o mundo contemporâneo conhece tentativas de chegar à plena realização humana sem contar com Deus. Este desafio à fé só pode ser enfrentado a partir da proposta cristã sobre Deus e o homem. A partir daí podem ser delineados elementos a considerar ao se colocar hoje a questão de Deus. É primeiro traçada a relação entre a visão bíblica e a filosófica de Deus. Em seguida, é tratada a possibilidade da afirmação de Deus, considerada em três vias de acesso: a partir da realidade, a partir da existência do homem e do mundo, a partir da inteligibilidade da natureza e, enfim, a partir da experiência ética.

Palavras-chave: Pós-modernidade; Fé e cultura; Ateísmo pós-moderno

\footnotetext{
${ }^{1}$ Tradução de Maria de Lourdes Corrêa Lima, Doutora em Teologia Bíblica pela Pontifícia Universidade Gregoriana (Roma), Professora do Departamento de Teologia da PUC-Rio e do Instituto Superior de Teologia da Arquidiocese do Rio de Janeiro.
} 


\section{Résumé}

L'auteur traîte le thème de Dieu et questionne la possibilité de la foi dans le contexte culturel comtemporain. Bien que l'histoire montre que la relation de l'homme avec la religion et avec Dieu est une réalité constante dans les diverses cultures, le monde moderne tente d'arriver à sa pleine réalisation humaine sans compter avec Dieu. À ce défi à la foi on ne peut faire front qu'a partir de l'idée chrétienne de Dieu e de l'homme. De là résultent des éléments qui doivent être considérés pour pouvoir, aujourd'hui, poser la question de Dieu. D'abord, est définie la relation entre la vision biblique et la philosophique de Dieu. Ensuite, est traîtée la possibilité de l'affirmation de Dieu, en considérant trois voies d'accès: à partir de la réalité (l'existence de l'homme et du monde), à partir de l'intelligibilité de la nature et, enfin, à partir de l'expérience éthique.

Paroles-clef: Postmodernité, foi et culture, athéisme postmoderne

\section{Como se colocam hoje a pergunta acerca de Deus e a fé em Deus 1. A pergunta acerca de Deus é, hoje, uma pergunta aberta}

As grandes e profundas mutações sócio-culturais já ocorridas e atualmente em curso estão sendo apresentadas nas colocações de Mons. Romera e Mons. Carrasco. Abordarei então, diretamente, o tema de Deus e da fé nEle, no contexto cultural contemporâneo.

Inicio narrando um episódio da minha juventude. Há mais de 60 anos, quando era estudante do liceu científico de Modena e tinha cerca de 17 anos, um dia, insolitamente, durante a viagem de trem para a escola, surgiu entre nós estudantes uma pequena discussão sobre a existência de Deus. Os primeiros que se expressaram disseram, em substância, que sobre Deus não era possível ter certezas: era isto que tinham ouvido do nosso professor de história e filosofia. Eu, que então não estava decerto entre os jovens mais assíduos à Igreja, respondi com decisão que, ao contrário, estava certo da existência de Deus. Retrucaram-me, maravilhados, que não entendiam como eu pudesse estar certo, quando os maiores pensadores tinham tido e continuavam a ter sobre este assunto opiniões muito diversas. Boa parte dos outros estudantes, porém, se calava e, só muito tempo depois, compreendi que aqueles que se calavam acreditavam e estavam silenciosamente de 
acordo comigo. Este pequeno episódio, que remonta à segunda metade dos anos 40, pouco depois do fim da segunda guerra mundial, em minha opinião poderia muito bem repetir-se entre os jovens de hoje e é o sinal de uma situação que, ao menos na Itália, em sua substância, mudou muito menos do que normalmente se pensa.

Passando dos episódios pessoais aos estudos que abordaram de modo mais aprofundado o problema da fé em Deus hoje, faço referência, sobretudo, à imponente obra do filósofo, historiador e sociólogo canadense Charles Taylor L'età secolare (A Secular Age), publicada em 2007. Ele nega que exista uma relação automática entre modernidade e perda ou diminuição da fé em Deus. Isto pode ser verdadeiro para alguns países, como, por exemplo, os do norte da Europa, mas não para todos: por exemplo, não é verdadeiro para os Estados Unidos da América. A clara distinção entre política e religião, como também entre a religião e as outras dimensões da existência (econômicas, científicas, artísticas, recreativas...), é já uma característica comum das atuais sociedades democráticas, mas também este fato não se opõe por si mesmo à fé em Deus, embora certamente não a torne mais fácil. A mudança decisiva ocorrida neste campo pode, ao contrário, ser resumida assim: desde a metade do século dezenove, portanto já há cento e cinquenta anos, passamos de uma sociedade na qual era "virtualmente impossível não crer em Deus, a outra em que também para o fiel mais devoto esta possibilidade (de crer em Deus) é só uma possibilidade humana entre outras". O verdadeiro núcleo da secularização, segundo Taylor, está exatamente aqui: em considerar a fé em Deus como uma opção entre outras.

Pessoalmente, encontro-me nesta análise e também nas indicações de princípio que Taylor - um católico sincero - extrai dela. Em seu parecer, afirmou-se no Ocidente, não só entre as pessoas de cultura, mas mesmo também entre as pessoas comuns, a convicção de um "florescer do homem", isto é, de um ideal de plenitude de vida que seria possível sem Deus. É este hoje, para a fé, um desafio decisivo, um desafio claramente não só intelectual, mas espiritual, moral, existencial, ao qual se pode responder não se limitando a criticar a sensibilidade atual e a colocar em evidência seus indubitáveis limites, mas haurindo da riqueza da proposta cristã sobre Deus e sobre o homem, para oferecer a esta sensibilidade uma possibilidade de realização muito mais plena e muito maior. Na base está a certeza, confirmada também pelos desenvolvimentos atuais da história, de que a relação do homem com a religião e com Deus é tão profunda que, quando mudam também radicalmente os contextos 
sociais e culturais, a pergunta religiosa não se extingue, mas se recompõe em formas mais adaptadas à nova situação.

\section{Como enfrentar aquela pergunta}

É neste quadro que gostaria de precisar, de modo mais sistemático, a atitude com a qual se deve colocar a questão de Deus. Antes de mais nada, devemos renunciar à pretensão de uma abordagem "neutra", puramente objetiva ou científica. A questão de Deus, de fato, envolve inevitavelmente a pessoa, o sujeito que a põe, pois tem a ver com o sentido e a direção da nossa vida e com o modo como interpretamos a nós mesmos e a toda a realidade. Por isso é correto dizer que, com Deus ou sem Deus, tudo muda. Mais precisamente, também a resposta à pergunta "faz diferença se Deus existe ou não?" muda profundamente conforme quem a responde seja uma pessoa de fé ou não (ateu ou agnóstico). Os crentes autênticos respondem que a diferença existe e é grande e radical - antes, é a primeira e maior diferença -, porque Deus é a origem, o sentido e o fim do homem e do universo. Os não crentes, ao contrário, podem diferenciar-se na sua resposta, conforme considerem a fé em Deus como negativa, positiva ou irrelevante para a vida do homem e da sociedade. Mas, propriamente falando, referem-se somente à nossa fé em Deus, não à realidade mesma de Deus, uma vez que, em seu parecer, Deus não existe ou, de qualquer modo, não podemos saber nada dele, nem mesmo se ele existe.

Como observou o então Cardeal Ratzinger (L'Europa di Benedetto nella crisi delle culture, 2005), não existe, no que concerne a Deus, nem sequer um espaço de neutralidade que possa consistir em refugiar-se numa posição agnóstica: o agnosticismo pode ser, de fato, afirmado teoricamente, mas é muito mais difícil de se viver praticamente. Na prática, somos forçados a escolher entre as duas alternativas já indicadas por Pascal: ou viver como se Deus não existisse ou viver como se Deus existisse e fosse a realidade decisiva da nossa existência. Se nos comportamos conforme a primeira alternativa, adotamos de fato uma posição ateia e não somente agnóstica. Se, ao contrário, decidimo-nos pela segunda alternativa, adotamos uma posição crente: em concreto, a questão de Deus não pode, portanto, ser evitada.

É necessário imediatamente acrescentar, porém, que, por mais que a questão de Deus possa ser importante e decisiva para a nossa vida e para a interpretação de toda a realidade, não podemos, todavia, parar neste 
aspecto. Devemos enfrentar de modo direto também a pergunta acerca da realidade de Deus, isto é, de sua existência ou não existência. Se, de fato, Deus não existisse, qualquer reconhecimento da sua importância para nós permaneceria inevitavelmente suspenso no vazio; antes, seria ilusório. Por conseguinte, a pergunta à qual a própria vida remete é, em última análise, a pergunta se Deus existe ou não (e, inseparavelmente, quem ou o que ele é). A esta pergunta é necessário dedicar toda a diligência e o rigor de nossa inteligência, embora permanecendo sempre conscientes de que não se trata de uma questão puramente intelectual e teorética.

Além disso, a própria impossibilidade de uma abordagem neutra à questão de Deus não constitui somente um limite nosso. Ao contrário, encerra um significado fortemente positivo, que consiste exatamente no total envolvimento de nós mesmos, da nossa experiência de vida, da liberdade e dos afetos, juntamente com a inteligência e suas capacidades críticas. Verdadeira é, especialmente no tocante a este ponto, a palavra de Santo Agostinho: "conhece-se realmente só o que se ama realmente" (aqui Agostinho é o eco fiel do capítulo 4 da primeira Carta de São João). Especialmente quando se trata de Deus, é errôneo, portanto, fechar-se numa perspectiva racionalista.

\section{Deus na história}

\section{O testemunho da história das religiões}

Uma confirmação da relação profunda que une o homem à religião e a Deus nos vem da história e da fenomenologia das religiões, tal como apresentadas e interpretadas hoje por um grande estudioso belga, o sacerdote católico Julien Ries. Desde as suas origens como animal capaz de pensamento simbólico, o homem nos aparece, de fato, através dos achados pré-históricos e, em seguida, dos testemunhos mais antigos da história, como "alguém que busca o infinito"; alguém que, no ato mesmo de erguer-se sobre as próprias pernas (homo erectus) e de tomar consciência de si, abre-se à transcendência, especialmente na contemplação da abóbada celeste - isto é, toma consciência da existência de uma realidade totalmente diferente do próprio homem e do seu mundo quotidiano - e, ao mesmo tempo, torna-se consciente do próprio limite, com o emergir do sentimento de angústia frente à morte. Assim, bem antes do formar-se - com o homo sapiens sapiens - das religiões propriamente ditas, o homem faz a experiência do sagrado e se caracteriza como homo religiosus, de modo a poder afirmar que "o homem 
religioso é o homem normal". A dimensão religiosa é, portanto, um dado imediato da consciência do homem, que surge de um sentido de estupor diante de algo que o supera infinitamente; e não é, ao contrário, como pensaram muitos críticos modernos da religião, algo de secundário, que nasceria de uma necessidade, em particular da tentativa de dar remédio à própria culpa ou finitude.

\section{O Deus bíblico e sua relação com o Deus dos filósofos}

No que concerne às religiões propriamente ditas, é muito interessante para nós a questão dos desenvolvimentos do monoteísmo. Já a partir do sexto século antes de Cristo, afirmou-se na Grécia uma crítica racional e filosófica do mito, a qual tendia a substitui-lo pelo logos, o discurso racional, quanto ao conhecimento da realidade de nós mesmos e do mundo, embora deixando-lhe um espaço para orientar a vida daqueles que não são capazes de valer-se plenamente do logos, e também, em alguma medida, para alcançar aquelas realidades mais altas às quais o logos do homem não pode chegar com certeza. Em todo o caso, a filosofia grega não é de nenhum modo "ateia", ao menos nas suas expressões mais importantes. Ao contrário, qualifica-se a si mesma também com o nome de "teologia": uma teologia, porém, não mais "mítica", mas "física", isto é, natural e racional, capaz de apreender a verdadeira natureza do divino. Seria demasiadamente precipitado afirmar que esta teologia filosófica era propriamente monoteísta, mas ela, de qualquer forma, concebe a realidade suprema como unitária, como o Uno que está no ápice de tudo. O problema é, antes, que a este Uno ou Absoluto os homens não se podem dirigir, não podem entrar em uma relação pessoal com ele: por isso, a oração, atitude fundamental do homem religioso, não pode ser endereçada a ele. Ela pode encontrar um significado e uma motivação só em um plano diferente, como expressão das nossas necessidades existenciais e sociais, dirigindo-se em concreto àqueles deuses que, na realidade, são somente imagens do Absoluto, construídas por nós em função de nossas necessidades.

É interessante notar que, na mesma época (VI século a.C.), numa área geográfica e cultural bem diferente, isto é, na Índia, nascia o budismo, o qual pode, também ele, entender-se como uma crítica das precedentes formas de religião mítica e que igualmente não deixa espaço à oração entendida como uma relação pessoal com um Tu divino, reconduzindo cada coisa à não distinção do "Nada" indiferenciado, no qual todo "eu" e todo "tu" se dissolve, inclusive um suposto "Tu" divino. 
Sempre no mesmo período, uma crítica ainda mais radical do politeísmo foi desenvolvida pelos profetas de Israel, em particular pelo Dêutero-Isaías (Isaías 40-55), escrito em torno aos anos 550-539 a.C. Ao menos neste texto do Antigo Testamento, e em tantos outros que hoje, erroneamente ou com razão, tende-se a considerar como posteriores ou, no máximo, contemporâneos ao Dêutero-Isaías, está claramente presente um forte e decidido monoteísmo, com a negação da existência de qualquer outra divindade fora Jahweh. Isto é, o Deus de Israel é o único Criador e Senhor do céu e da terra, que também todos os outros povos são chamados a adorar e a reconhecer. Anteriormente, segundo estas novas tendências historiográficas, em Israel teria havido somente um "henoteísmo", isto é, um culto a Jahweh como Deus supremo, que, porém, não excluía outras divindades subordinadas, ou, no máximo, uma "monolatria", ou seja, o culto de um só Deus, Jahweh, o Deus "ciumento" que - sem negar a existência de deuses dos outros povos - exigia um culto exclusivo de Israel, seu povo.

De qualquer modo, somente na Bíblia, ao menos a partir do Dêutero-Isaías, encontramos o monoteísmo em sentido próprio e pleno, que consiste não simplesmente em afirmar a unicidade do Ser supremo, mas também em poder relacionar-nos a ele e a rezar a ele, e na consequente exclusão do culto de outras divindades. Assim a revelação bíblica superou radicalmente aquela separação que atormentava a religião na antiguidade clássica, reunificando no único Deus que se revela a nós o Ser absoluto - ao qual tinham chegado, de algum modo, os filósofos - e aquelas divindades a quem se podia prestar culto, mas que então tinham sido reduzidas, pela crítica filosófica, a um mito desprovido de verdade e substância.

Numa perspectiva histórico-religiosa, uma separação em certos aspectos semelhante a esta parece ter ocorrido já muitos milênios antes: de fato, a crença num Ser supremo se verifica praticamente em todos os povos e mitos arcaicos, mas progressivamente este Deus supremo parece afastar-se do mundo e dos homens, desinteressar-se deles e abandonar o próprio poder a divindades inferiores, tornando-se assim um Deus otiosus, um "Deus ocioso" e, como tal, sempre menos objeto de interesse e de oração. A revelação bíblica coloca-se, portanto, como uma reviravolta grandiosa e decisiva na história da religião e das religiões: o Deus supremo agora toma a iniciativa, irrompe no cenário do mundo e na vida do homem, apresentando-se como o "Deus ciumento" que quer unicamente para si a oração, o culto e a adoração, pois só ele é Deus e todo o resto é criatura sua. 
Com Jesus Cristo e o cristianismo é superado o problema do liame especial entre o único Deus criador universal e unicamente o povo judaico: este único Deus se propõe como salvador, sem discriminações, de todos os povos. A afirmação histórica do Deus de Jesus Cristo no mundo antigo apresenta dois aspectos de grande interesse. De um lado, o cristianismo realiza uma opção clara e consciente pelo logos e não pelo mito, colocando seu Deus do lado da racionalidade filosófica e não das religiões míticas. Não se trata, de resto, de uma total novidade, já que uma tal opção fora já prefigurada no judaísmo helenístico, como testemunha a tradução grega do Antigo Testamento chamada dos "Setenta". A afirmação "No princípio era o Logos", com que se inicia o Prólogo do Evangelho de João, constitui, sob este ponto de vista, "a palavra conclusiva sobre o conceito bíblico de Deus, a palavra na qual todas as vias muitas vezes fatigantes e tortuosas da fé bíblica chegaram à sua síntese", como afirmou Bento XVI no célebre discurso na Universidade de Regensburg. Na mesma linha é interpretado o nome "Eu sou", com que Deus se auto-apresenta a Moisés na cena da sarça ardente de Êxodo 3,14, para chegar até à aplicação deste "Eu sou" a si mesmo que Jesus faz no Evangelho de João 8,24.28.58. Os grandes Padres da Igreja, em particular Santo Agostinho, caminharam na mesma direção.

Assim temos, no entanto, somente uma metade do discurso: a outra metade constitui-se da novidade e diferença profunda da revelação bíblica no que tange à racionalidade grega, antes de tudo no que se refere ao tema próprio de Deus. O Deus de Jesus Cristo e da fé cristã supera radicalmente, com efeito, aquilo que os filósofos tinham pensado acerca dEle. Em primeiro lugar, Deus é claramente distinto da natureza, do mundo que Ele criou: só assim a "física" e a "metafísica" chegam a uma clara distinção uma da outra. E sobretudo, como já observamos, este Deus não é uma realidade inacessível a nós, que nós não podemos encontrar e à qual é inútil dirigir-se na oração, como julgavam os filósofos. Ao contrário, o Deus bíblico ama o homem e por isso entra na nossa história, dá vida a uma autêntica história de amor com Israel, seu povo, e, depois, em Jesus Cristo, não só estende esta história de amor e de salvação para a humanidade inteira, mas a conduz ao extremo, isto é, ao ponto de "voltar-se contra si mesmo", na cruz do próprio Filho, para elevar o homem e salvá-lo, e de chamar o homem àquela união de amor com Ele que culmina na Eucaristia (cfr Deus caritas est, nn. 9-15, onde Bento XVI resume com grande força o que aprofundara desde os inícios de seu trabalho de teólogo).

Portanto, o Deus - que é o Ser e o Verbo - que é também e identicamente a Agápe, o Amor originário e a medida do amor autêntico, que exatamente por 
amor criou o universo e o homem. Mais precisamente, este amor é totalmente desinteressado, livre e gratuito: Deus, de fato, cria livremente o universo do nada (só com a liberdade da criação torna-se plena e definitiva a diferença entre Deus e o mundo, não existindo mais nenhum vínculo necessário que ligue Deus ao mundo, mas só o vínculo de total dependência criatural que liga o mundo a Deus) e livremente, por sua misericórdia sem limites, salva a humanidade pecadora. Chegam assim a plena reconciliação aquelas duas dimensões da religião que antes estavam separadas uma da outra, isto é, o Deus eterno do qual falavam os filósofos e a necessidade de salvação que o homem traz dentro de si e que as religiões pagãs tentavam de algum modo satisfazer. O Deus da fé cristã é, portanto, o Ser absoluto, o Deus da metafísica, mas é também e identicamente o Deus pessoal e trinitário, que é o Deus da história e não somente da metafísica, o Deus que entra na mais íntima relação conosco. É esta a única resposta adequada à célebre questão, posta por Pascal, do Deus da fé e do Deus dos filósofos, uma resposta que a própria teologia cristã ainda não elaborou totalmente e que terá sempre diante de si como sua tarefa fundamental e inexaurível: isto é, a tarefa de desenvolver, integrar e corrigir na sua limitação e nos seus bloqueios - à luz da revelação que Deus fez de si mesmo - o conceito de Deus até hoje elaborado pela tradição filosófica e também teológica (J. Ratzinger examinou esta temática de modo inovador e profundo desde a solene aula de abertura de seu magistério, em 1959, na Universidade de Bonn, intitulada exatamente O Deus da fé e o Deus dos filósofos. Uma contribuição ao problema da theologia naturalis).

\section{O eclipse de Deus no Ocidente}

De alguns séculos para cá, porém, a fé neste Deus e, ainda antes, seu lugar central na cultura do Ocidente entraram progressivamente em dificuldade. Examinaremos em breve duas razões principais desta crise: no momento, gostaria somente de especificar algumas etapas fundamentais que marcaram seu percurso. Já no início do pensamento moderno, o Deus dos filósofos começou a tomar distância do Deus do cristianismo, em alguns casos sem que os próprios filósofos, que frequentemente eram profundamente cristãos, disto se dessem conta. Deus tornou-se, assim, um "objeto" que se encontra diante do pensamento do homem e, de alguma maneira, pode ser dominado por ele. $\mathrm{O}$ passo seguinte teve rapidamente lugar: Deus e as religiões devem estar dentro dos limites da pura razão. Portanto, as religiões positivas, inclusive o 
cristianismo, não teriam uma verdade própria e seriam válidas somente na medida em que ajudassem o povo a aproximar-se deste Deus da pura razão. Deste modo, claramente, falta o conceito mesmo de revelação: não é mais Deus que se revela a nós, mas é somente a nossa razão que chega a conhecer a Deus. Esta perda da revelação é hoje, no horizonte da nossa cultura, muito evidente e prenhe de consequências.

Muito rapidamente, porém, também este Deus da razão é declarado racionalmente não cognoscível, porque é um objeto que está para além de toda experiência possível de nossa parte. E finalmente este Deus é remetido novamente a uma espécie de projeção de nossos desejos e de nossas contradições e, portanto, é declarado não existente, puramente ilusório. A célebre fórmula de Nietzsche acerca da "morte de Deus" - morte na nossa cultura mas também não existência na realidade - é realmente o denominador comum de grande parte da cultura contemporânea, caracterizada pelo assim chamado "fim da metafísica", cujo significado prático é que existe na realidade só o mundo empírico, o universo físico, objeto dos conhecimentos científicos. Certamente são muito diferentes as interpretações propostas desta única realidade e procura-se, de várias maneiras, encontrar espaço para os significados espirituais que respondam à abertura para o infinito que é presente dentro de nós. Permanece, porém, o limite de fundo, segundo o qual, em última análise, não existiria outra realidade a não ser a "física".

É interessante observar que uma variante recente destas posições de fundo é a crítica do monoteísmo, ao qual é contraposta a superior "humanidade" do politeísmo, aberto e tolerante, enquanto que o monoteísmo seria, ao contrário, exclusivo e violento, porque introduz na religião - isto é, no vértice da realidade - a distinção entre o verdadeiro e o falso (o verdadeiro Deus e os falsos deuses), que seria a origem última da intolerância e da violência. A esta tese, apresentada, por exemplo, por J. Assman no seu livro Mosè l'egizio, deu uma resposta realmente convincente o então Cardeal Ratzinger no volume Fede Verità Tolleranza. Il cristianesimo e le religioni del mondo, publicado em 2003. Nele se põe às claras como a distinção "mosaica" entre verdadeiro Deus e falsos deuses - portanto, antes de tudo entre o verdadeiro e o falso - é também a distinção operada por Sócrates na sua polêmica contra os sofistas e que ela é inseparável de uma outra distinção, entre o bem e o mal, também esta mosaica e socrática e igualmente fundamental para a vida do homem e para o desenvolvimento da civilização.

À fórmula da "morte de Deus" como interpretação do destino do Ocidente, 
pode-se contrapor com boas razões a outra fórmula, proposta por Martin Buber, que fala de "eclipse de Deus": segundo esta, só provisoriamente a nossa cultura perdeu o seu Deus. O que observávamos no início, baseando-nos nos estudos de Ch. Taylor, acerca da fé em Deus ainda hoje plenamente possível, embora junto com a não crença, constitui o motivo principal para sustentar que Deus, também no plano histórico e cultural, pode de novo tornar-se presente no mundo; antes, jamais deixou de sê-lo.

Para que esta presença tome novo vigor e possa obter, embora de modos diferentes daqueles do passado e muito mais caracterizados pela livre opção pessoal de cada um, uma forte relevância na cultura do nosso tempo, parecem necessárias algumas condições, sobre as quais procuraremos refletir nos nossos encontros seguintes.

\section{Conhecimento de Deus e revelação}

\section{Dimensão objetiva e subjetiva da revelação de Deus a nós}

Uma destas condições, provavelmente não a existencialmente mais importante, mas certamente aquela sem a qual todo o resto permaneceria destituído de consistência, diz respeito à existência mesma de Deus, que devemos demostrar exatamente por ser menos razoável e plausível para a cultura do nosso tempo.

A este propósito, a lembrança de nossos estudos filosóficos e teológicos suscita provavelmente em nós um certo mal-estar: a questão da existência de Deus era confiada, de fato, de modo quase exclusivo, ao tratado filosófico chamado "teologia natural" ou "teodiceia", com o forte perigo que o discurso aparecesse bastante abstrato e distante de nós. O Concílio Vaticano I, na Constituição dogmática Dei Filius, já havia proposto, porém, uma abordagem da existência de Deus muito mais ampla, afirmando que o homem, com a sua razão natural, pode conhecer com certeza a Deus, a partir das coisas criadas; acrescentando imediatamente, porém, que, dadas as condições efetivas em que se encontra o gênero humano (em consequência do pecado original), é necessário que Deus mesmo se revele a nós, não só para nos fazer conhecer o mistério da nossa salvação, mas também para que todos possam conhecer com facilidade, com firme certeza e sem erros aquilo que, no que lhe concerne, por si mesmo não é inacessível à nossa razão. Esta revelação se realiza através dos eventos e das palavras da história da salvação e atinge sua plenitude em Jesus Cristo, como 
ensina o Concílio Vaticano II (Dei Verbum, 2). Esta dimensão, por assim dizer "objetiva" ou "externa", da revelação é constantemente acompanhada da ação do Espírito Santo, que, operando dentro de nós, abre nossa inteligência e move nosso coração para acolher na fé Deus que se revela (cfr Dei Verbum, 5). Além disso, o Espírito Santo opera invisivelmente em todos os homens de boa vontade - mesmo não explicitamente crentes -, dando-lhes a possibilidade de entrar em contato, de modo como só Deus conhece, com o mistério da nossa salvação (Gaudium et Spes, 22). Esta que poderíamos chamar a dimensão "interior" e "subjetiva" da revelação se realiza no concreto da nossa existência e assume formas e faces sempre novas, encarnando-se na infinita variedade das experiências e das circunstâncias de que é feita a vida de cada um de nós: entre estas, tem certamente um peso particular o encontro com pessoas que, com a própria vida, sejam autênticas testemunhas de Deus. A abertura a Deus e a nossa adesão a ele são, portanto, antes de tudo, fruto de sua iniciativa e não podem ser confinadas nos estreitos limites de algum conceito ou esquema mental nosso.

Os motivos concretos pelos quais cada um de nós crê em Deus são, portanto, muito pessoais. A dimensão "objetiva” da revelação, que tem seu centro em Jesus Cristo, é dotada, porém, de motivos de credibilidade que superam a experiência pessoal e se propõem à atenção de todos. $\mathrm{O}$ primeiro e mais importante destes motivos é o próprio Cristo, em sua vida, seu ensinamento, nas obras por ele realizadas e, de modo especial, na sua ressurreição dos mortos. Em torno a Jesus Cristo, à sua cognoscibilidade histórica, à consciência que ele tinha de si mesmo, à sua ressurreição e finalmente à sua misteriosa realidade, desenvolveu-se, desde há quase três séculos, um enorme debate, que conheceu e continua a conhecer muitas fases sucessivas. Não é certamente possível entrar aqui em tal debate, nem mesmo por alto. Parecem-me, todavia, indispensáveis algumas observações. A primeira é que a tradição de Jesus, que nos é conservada principalmente nos Evangelhos sinóticos, é muito mais atendível e historicamente fundada do que frequentemente se supôs e se supõe: uma motivada confirmação desta atendibilidade é oferecida, por exemplo, pelo importante estudo de James D. G. Dunn, La memoria di Gesù, publicado em 2003. A segunda observação diz respeito à ressurreição. As aparições de Jesus ressuscitado, embora na variedade das tradições, estão na base do testemunho unânime do Novo Testamento, que as entende sempre em sentido realista, isto é, como realidade efetivamente acontecida, e não só como experiências subjetivas dos discípulos. O que São Paulo escreve a este respeito em 1Cor 15 exprime a convicção e a certeza partilhadas por todos os 
autores do Novo Testamento. Mesmo a tradição do sepulcro vazio se mostra, sob um exame crítico, resistente a toda interpretação redutiva. Sem a realidade da ressurreição permaneceria inexplicável, além disso, o desenvolvimento rapidíssimo da cristologia, amplamente atestado pelo Novo Testamento, por exemplo já no antiquíssimo hino a Cristo de Fil 2,6-11. Chegamos assim a uma terceira consideração, que interessa diretamente à questão da existência de Deus. As tentativas sempre renovadas de confinar os eventos de Jesus de Nazaré nos limites de um acontecimento histórico puramente humano têm todos, com efeito, um pressuposto comum, tácito ou explícito: evitar a questão de Deus e excluir uma intervenção direta de Deus na história. Mas estas tentativas, no final, são sempre forçadas a reduzir a mito o que pertence, ao contrário, à história, ou então a recorrer a outras hipóteses historicamente muito improváveis.

Também na subsequente história do cristianismo (e já antes no Antigo Testamento, como acenamos ao falar das origens do monoteísmo) não faltam as experiências que abrem à pergunta acerca de Deus: tais são não só os milagres e outros sinais de uma especial intervenção de Deus, mas também as experiências de Deus que tiveram os grandes místicos e, em geral, muitos santos. Nesse sentido, o Concílio Vaticano I fala da Igreja como grande sinal levantado em meio às nações.

Esta abordagem da existência de Deus radicada na história do cristianismo está, de resto, em sintonia com aquela mudança em sentido existencial e histórico que caracterizou os desenvolvimentos culturais dos últimos séculos.

\section{A cognoscibilidade racional de Deus segundo o magistério da Igreja}

Não vem a faltar, todavia, o espaço, antes, a necessidade de uma reflexão racional sobre Deus, e principalmente sobre sua existência, que tome em consideração não determinadas experiências históricas, mas a estrutura e a consistência da realidade inteira de que temos experiência e, particularmente, do sujeito humano enquanto tal, na sua especificidade de sujeito capaz de colocar-se o problema de Deus, ou seja, de procurar conhecê-lo.

Para um católico, a questão da cognoscibilidade de Deus por parte da razão humana não é uma questão em que qualquer opinião seja igualmente aceitável, como emerge de uma série de tomadas de posição do magistério da Igreja, desde o pronunciamento já lembrado do Concílio Vaticano I sobre a cognoscibilidade natural de Deus a partir das coisas criadas, até o Catecismo da Igreja 
Católica (nn. 36-38 e, mais amplamente, 27-49). Na sua base está a afirmação da Carta aos Romanos 1,18-20: "A ira de Deus se revela do céu contra toda impiedade e toda injustiça de homens que sufocam a verdade na injustiça, pois o que de Deus se pode conhecer lhes é manifesto; Deus mesmo lho manifestou. De fato, as suas perfeições invisíveis, ou seja, sua eterna potência e divindade, são contempladas e compreendidas desde a criação do mundo através das obras por Deus realizadas". Em síntese, para o magistério é possível um conhecimento de Deus a partir das criaturas (o Catecismo da Igreja Católica especifica: a partir do universo e a partir do homem); neste conhecimento, porém, o homem encontra dificuldades tão grandes que há a necessidade moral de que Deus mesmo se revele para poder ser conhecido por todos, com firme certeza e sem erros, como já acenamos. Segundo a interpretação teológica do magistério que hoje largamente prevalece, o conhecimento puramente natural de Deus é "possível"; não é dito, porém, que seja também atual, isto é, que se tenha jamais verificado em algum sujeito humano. Esta última questão não pode ser resolvida de um ponto de vista teológico; ao contrário, parece pouco sensata, uma vez que é bem difícil excluir uma intervenção de Deus que ilumine a partir de dentro a inteligência, mova a vontade, abra o coração para crer nele. Todavia, tem grande importância a questão da validade que, por si mesma (ou seja, prescindindo dos obstáculos que de fato a impedem de desenvolver-se), tem ou não a via racional de acesso Deus: a esta validade se liga, com efeito, a característica de poder ser proposta a todos - e não só aos crentes de uma ou outra religião - a existência de Deus (e, portanto, a possibilidade de um discurso público a respeito de Deus) e a própria abertura universal da missão cristã. Por estes motivos, a Igreja se pronuncia numa matéria que poderia parecer puramente "filosófica".

\section{Características e dificuldades atuais das trajetórias racionais de acesso a Deus}

\section{Podemos chegar racionalmente a Deus somente a partir das realidades que experimentamos}

Devemos, então, procurar propor algumas trajetórias de acesso a Deus que sejam o mais possível compreensíveis e convincentes para a razão contemporânea. Partamos da realidade oferecida à nossa experiência e especialmente da realidade do sujeito humano, tendo criticamente presentes as capacidades e os limites do nosso conhecimento. Não gostaria de limitar-me, porém, 
a colocar em ordem trajetórias, mas sim de apresentá-las em sua relação recíproca e, finalmente, como uma unidade de coisas distintas.

Inicio com algumas exclusões. Não me parecem consistentes as vias "a priori", sejam aquelas do "argumento ontológico", nas suas várias formas, porque contêm sempre uma passagem da ordem dos conceitos à ordem da existência que não pode ser justificada ao se trabalhar somente sobre conceitos; sejam as outras vias, que apelam a um conhecimento racional imediato de Deus, como se ele nos fosse conhecido por si mesmo. É bem verdade, com efeito, que - para quem crê nele - Deus, em si mesmo, é a realidade, a verdade e o bem primeiro e originário, que está na base de todas as outras realidades, verdades e bens; mas não é primeiro e nem tampouco por si mesmo evidente para a nossa inteligência: isto é, vale a distinção de São Tomás (Summa Theologiae, I, q.2, a.1), segundo a qual conhecemos imediatamente a Deus somente de maneira indeterminada ("in aliquo communi"), sob o conceito geral de bem-aventurança (ou de ser, ou de verdade), mas não na sua distinta e própria existência.

Para uma abordagem racional da existência de Deus restam então como praticáveis somente trajetórias a posteriori, em concreto a partir da existência de realidades de que temos experiência, sejam elas o universo ou o próprio homem.

Acrescento imediatamente um ulterior esclarecimento e delimitação. A passagem racional das realidades objeto de experiência à realidade de Deus é sempre, afinal, uma passagem filosófica e, mais precisamente, metafísica. Para chegar por via racional à existência de Deus, não são, portanto, suficientes as abordagens científicas, uma vez que as ciências modernas se distinguem, com razão, da filosofia e em particular da metafísica. Não bastam tampouco as abordagens que apelam à experiência moral ou à experiência estética e às exigências nelas implícitas, a menos que sejam integradas por uma passagem propriamente metafísica. Caso contrário, com efeito, arrisca-se a permanecer dentro de um discurso do "como se" (como se Deus existisse), que pode mostrar certamente o quanto pode ser desejável e almejável para nós que Deus exista, mas nem por isso conclui acerca de sua efetiva existência.

As trajetórias a posteriori assim especificadas devem-nos conduzir a responder não somente à pergunta se Deus existe (an Deus sit), mas também, ao menos de alguma maneira, à pergunta sobre quem, ou o que, ele é (quid Deus sit), isto é, a alguma explicação, embora limitada, imperfeita e somente analógica, da sua natureza ou essência. Em caso contrário, com efeito, a própria afirmação da existência de Deus acabaria por ser destituída de todo sentido e conteúdo determinado. 


\section{A dificuldade moderna e o problema de sempre no caminho racional de acesso a Deus}

Exatamente sobre estas trajetórias a posteriori das realidades de que temos experiência até Deus, sobre sua legitimidade e possibilidade, concentrou-se - como é sabido - a crítica filosófica moderna: a Crítica da razão pura de Kant permanece o fulcro desta contestação, com uma influência ainda hoje decisiva, particularmente no tocante a este tema.

Não podemos, por isso, deixar de dizer algumas palavras a esse respeito. Antes de mais nada, não deve ser silenciada a incoerência interna da Crítica da razão pura, devida ao muito discutido "elo que falta" (Bruch) na dedução transcendental: se, com efeito, os dados da experiência sensível são puramente amorfos, como sustenta Kant, fica sem explicação e inexplicável a ordem concreta com que eles são moldados pelas categorias do intelecto; se, ao contrário, não são totalmente amorfos, a "revolução copernicana" de Kant (segundo a qual não é o nosso conhecimento que se deve conformar à realidade, mas é "o objeto", em sentido kantiano, que se deve conformar às nossas categorias mentais) não é necessária e o "noumeno" - a "realidade em si” - não é puramente incognoscível.

Além disso, a crítica de Kant permanece dentro da análise dos conteúdos do conhecimento intelectual e não toma em consideração o seu exercício, o ato de conhecer; se atentamos a este ato, a redução daquilo que conhecemos intelectualmente ao único "objeto" em sentido kantiano, e não à própria realidade, revela-se, segundo penso, contraditória. De fato, quando afirmamos que o que conhecemos é somente o objeto e não a realidade, entramos em contradição com o próprio ato do juízo com que fazemos esta afirmação, uma vez que tal ato de juízo pretende valer incondicionalmente, isto é, pretende dizer respeito à realidade, e não valer somente dentro de um sentido limitado ao objeto kantiano. Caso contrário, permaneceríamos prisioneiros de uma petição de princípio, ou melhor, de uma tautologia: isto é, afirmar-se-ia que é verdadeiro, em sentido kantiano, que conhecemos somente o objeto, sempre em sentido kantiano. Também no que concerne a Kant vale, portanto, o argumento, de origem aristotélica, que reduz ao absurdo quem nega que o homem possa conhecer a verdade.

Dou-me conta de quanto esta impostação do discurso acerca de Deus implica recolocar em discussão a orientação que predomina no pensamento moderno e contemporâneo, mas julgo este recolocar em discussão inevitável, para que se dê novamente espaço à índole autêntica do nosso conhecimento 
e, contextualmente, ao primado do ser. Não penso de nenhum modo, além disso, que este recolocar em discussão traga consigo uma rejeição global de um tal pensamento e de suas grandes e preciosas aquisições, mas somente uma re-orientação sua, certamente profunda mas também fecunda e "libertadora" no que tange às restrições do próprio horizonte que o pensamento está atualmente assumindo.

Depois de Kant, ainda profundamente convencido da existência de Deus, afirmaram-se os chamados "mestres da suspeita" (Feuerbach, Marx, Nietzsche, Freud), que, de modo variado - como se disse - levaram Deus a ser uma projeção de nosso desejo. Esta suspeita está bem viva em nossa cultura e toda abordagem reflexiva de Deus deve hoje considerá-la, assim como considerar igualmente a crítica de Kant. Sem poder aprofundar o tema, limito-me a observar que nosso desejo de Deus não deve ser necessariamente interpretado no sentido de uma ilusão e de uma projeção de nós mesmos para fora de nós mesmos, projeção que geraria em nós divisão e frustração. Ao contrário, pode ser interpretado como sinal da nossa abertura para aquele Absoluto que, doando-se livremente a nós, seria o único capaz de preencher plenamente a radical não-auto-suficiência que se aninha no nosso querer assim como no nosso ser.

Um ulterior recolocar em discussão da legitimidade de qualquer abordagem metafísica de Deus foi realizado por Heidegger, que, por sua vez, exerce ainda uma notável influência. Ele, seguindo os passos de Nietzsche, criticou o que definiu como "ontoteologia", isto é, a confusão indevida entre teologia e ontologia. Não examinarei diretamente, aqui, esta crítica, mas a considerarei ao apresentar as trajetórias racionais para Deus.

O desenvolvimento das ciências cognitivas nas últimas décadas propõe com uma nova e, ao que parece, máxima radicalidade o problema da validade do nosso conhecimento da realidade. Por maiores que possam ser as contribuições que provêm destas ciências para uma melhor compreensão dos processos concretos do nosso conhecimento, a redução do problema propriamente gnoseológico do valor objetivo do conhecimento humano ao estudo de suas condições funcionais de exercício (e a implícita substituição, que daí segue, da doutrina filosófica do conhecimento por uma doutrina do conhecimento que seria "científica") parece não apreender o específico do conhecimento intelectual e de sua exigência de verdade.

A outra grande dificuldade no caminho para Deus, antes, uma pergunta muito mais existencialmente envolvente que a dificuldade do conhecimento, é a que nasce da existência do mal no mundo e, especialmente, das experiências 
do abismo de maldade que pode aninhar-se no coração dos homens, além da amplitude sem limites do sofrimento inocente. Esta interrogação angustiante nasce bem antes da época moderna e de sua exigência crítica: acompanha, de fato, toda a vida da humanidade. Na nossa época, porém, com a mudança da cultura em direção ao sujeito e a consciência mais clara que o sujeito humano tomou de si mesmo, de seus direitos e de sua "inviolabilidade", esta interrogação foi ulteriormente radicalizada, acabando, entre outras coisas, por entrar em conflito existencial (mas implicitamente também teorético) com a pertença do homem à natureza, a qual, por sua vez, é agora frequentemente interpretada como uma completa redução do sujeito humano à própria natureza. Criou-se, de fato, uma trágica incompatibilidade entre esta clara consciência de nós mesmos e a nossa submissão ao cego vir a ser de uma natureza destituída de significado. Os "mestres da suspeita" já lembrados e, ainda mais, muitos continuadores seus do século XX, deram voz e expressão antes de tudo à interrogação e ao sentido de rebelião que a experiência do mal, nas suas múltiplas formas, suscita em nós.

Diante desta interrogação, deve-se observar antes de tudo que não só o mal, mas também o bem existe amplamente no mundo e, especificamente, no homem, como bem moral e mesmo como santidade: portanto, também do bem deve ser dada a razão e, por este motivo, uma conclusão imediata acerca da não existência de Deus a partir da existência do mal não parece sustentável. De outro lado, porém, dentro de uma trajetória racional para Deus, a interrogação posta pela existência do mal não parece poder receber uma resposta plenamente convincente. A questão, portanto, permanece de alguma maneira não resolvida. Aqui se abre, portanto, a partir de dentro da investigação racional, o espaço para a necessidade de uma resposta mais alta, que, em última análise, só pode vir de Deus, com intuíra já Sócrates no célebre diálogo platônico Fédon, ao comparar o raciocínio humano a uma frágil jangada com a qual se navega pela vida, na expectativa de poder navegar com perigos menores em um veículo mais sólido ou num Lógos divino. Segundo a fé cristã, o Lógos feito carne ofereceu-nos um tal veículo mais sólido, mesmo se racionalmente não compreensível, mediante aquele "voltar-se de Deus contra si mesmo" que se realiza, por amor, na cruz do Filho (cfr Encíclica Deus caritas est, 12). 


\section{As vias racionais para Deus}

\section{A via que parte da existência nossa e do mundo}

As três trajetórias racionais para a existência de Deus que proporei procuram então colocar-se como uma unidade de coisas distintas. São trajetórias a posteriori, que partem da realidade oferecida à nossa experiência: antes de tudo, a realidade de mim mesmo mas, também e inseparavelmente, a realidade do universo ao qual pertencemos. Articulam-se segundo os três "transcendentais" clássicos - o ser, o verdadeiro e o bem -, sempre com referência prioritária a nós mesmos enquanto existentes, capazes de conhecer e capazes de amar. São, portanto, trajetórias que permanecem muito radicadas na grande tradição filosófica e em particular metafísica. Procuram também, porém, considerar seriamente a distância histórica que nos separa dos períodos antigo e medieval de tais tradições, distância que se concretizou com força especial na mudança em direção ao sujeito, no grande desenvolvimento da dimensão crítica no pensamento moderno, no afirmar-se das ciências modernas, com a transformação radical da imagem do universo - e também do homem - que elas trouxeram e ainda trazem consigo.

A primeira trajetória, que poderíamos denominar "ontológica" mas a posteriori, toma início da constatação (imediatamente evidente e inegável, se não queremos cair, como vimos, numa contradição entre o que afirmamos e o ato com que o afirmamos) que existe algo ao invés do nada. Aqui surge espontânea a pergunta "por que existe algo ao invés do nada", clássica no pensamento filosófico de Leibniz a Heidegger. Ela exprime o maravilhamento diante do dado primário de que algo existe, isto é, diante do encontro com a realidade. Na própria experiência de que algo existe podemos distinguir, porém, entre a determinação particular desta coisa - pela qual eu sou eu mesmo, um outro homem é um outro homem, qualquer outra coisa é aquela coisa e não uma diversa, inserida naquele determinado contexto espacial e temporal - e o ato pelo qual ela existe: nos termos de São Tomás, o "ato de ser". Este último, de um lado é próprio e peculiar àquela realidade particular, mas, de outro, a supera em todos os aspectos, pois na base de toda experiência de qualquer realidade existente encontramos analogamente o ato de ser. Antes, pode-se e deve-se dizer que toda realidade da nossa experiência, em certo sentido, é e ao mesmo tempo não é: é como uma realidade bem concreta da experiência; não é na medida em que existe de maneira limitada, mutável, 
condicionada e transitória, portanto, não a partir de si mesma. Sob este ponto de vista, seu ato de ser não lhe pertence como próprio, mas, ao invés, lhe é dado, e somente assim a coloca no ser.

Por isso nossa inteligência não pode deixar de interrogar-se sobre a origem do ser das realidades que experimentamos e procurar esta origem numa realidade profundamente diferente, não condicionada e transcendente, à qual $\mathrm{o}$ ato de ser pertença como próprio, antes, que coincida com tal ato. Ao mesmo tempo, torna-se claro que esta fonte transcendente e, finalmente, inexprimível, não pode dar o ser às realidades do mundo a não ser de uma maneira conforme à própria incondicionalidade. Não pode, portanto, entrar em nenhuma série de causas mundanas nem ser ligada, por nenhum vínculo necessário, aos seus efeitos. Uma necessidade pode e deve subsistir só em direção inversa, por assim dizer, não de cima para baixo, mas unicamente de baixo para cima, no sentido que as realidades da nossa experiência não poderiam existir senão recebendo como dom, daquela fonte, o seu ato de ser. Portanto, os conceitos de causa e causalidade devem ser unidos, neste âmbito, aos de dom e doação, para exprimir de alguma maneira, segundo as modestas possibilidades da nossa compreensão e da nossa linguagem, a relação misteriosa entre as realidades da nossa experiência e a sua fonte transcendente (este modo de propor uma trajetória "ontológica a posteriori" para Deus, devo, em grande medida, a G. Lafont, Dieu, le temps et l'être, éd. du Cerf 1986, que se confrontou sobretudo com M. Heidegger, procurando superar, porém, sua crítica demasiadamente generalizada à metafísica como "ontoteologia").

São bem conhecidas as objeções que são contrapostas a todo uso transcendente do princípio de causalidade: em particular a crítica que disto fez Kant é ainda considerada por muitos como a palavra definitiva sobre este problema. Depois, com o afirmar-se da mecânica quântica, o princípio de indeterminação foi considerado uma confirmação científica da não universalidade, também dentro do mundo físico, do princípio de causalidade. É necessário, portanto, precisar, mesmo se muito brevemente, em que sentido nos referimos à expressão "princípio de causalidade", que na história do pensamento é onerada por mil equívocos. Não se trata do sentido que tal princípio assume nas ciências empíricas, para indicar uma sucessão necessária de fenômenos físicos, e nem simplesmente de uma extensão da causalidade de que fazemos experiência no nosso agir. O significado que lhe atribuímos (que poderíamos denominar "ontológico" ou "metafísico" e que procuramos mostrar concretamente, motivando a passagem das realidades da nossa experiência à realidade originária) é ao 
contrário, antes de tudo, o de não limitar de modo apriorístico nossa tendência a conhecer e, por conseguinte, de não subtrair-se às perguntas que a inteligência humana se coloca quando reflete cabalmente sobre a nossa experiência.

O âmbito sobre o qual nos podemos interrogar - ou seja, a intencionalidade do nosso conhecimento - é, de fato, ilimitado e não admite restrições, pois qualquer restrição provocaria automaticamente uma nova interrogação sobre a sua legitimidade. Tal âmbito ilimitado sobre o qual nos podemos interrogar é exatamente o ser, sobre o qual versam as duas perguntas fundamentais "se existe" ("an sit") e "o que é" ("quid sit"). Em concreto, o ser é aquilo que de alguma maneira conhecemos desde o início do uso da nossa inteligência e que, porém, permanece sempre também o ainda não conhecido, o objeto de toda pergunta ulterior. Deste modo é radicalmente superada a questão da "ponte" entre o pensamento e a realidade, que atormentou a filosofia moderna antes de Kant e que contribuiu para impulsionar o próprio Kant a realizar sua "revolução copernicana".

\section{A via que parte da inteligibilidade da natureza}

Nossa segunda trajetória racional para a existência de Deus tem uma profunda correspondência com a precedente: retoma, com efeito, sob a ótica do nosso conhecimento o que até o momento tínhamos considerado sob a ótica do ser. Seu ponto de partida é a constatação de que o universo, mesmo que de modo sempre imperfeito e sujeito a revisão, pode ser conhecido pelo homem. Todas as tentativas de conhecer a nós mesmos e à natureza que a humanidade desde sempre fez no curso dos milênios têm este pressuposto fundamental. $\mathrm{O}$ nascimento e desenvolvimento das ciências modernas e das respectivas tecnologias, com sua específica racionalidade e fecundidade operativa, que constituem algo de novo e muito relevante na história do pensamento, pressupõem, com maior razão, a cognoscibilidade do universo e permitem apreender com particular clareza que não se trata de simples experiência sensível, mas de verdadeira e própria inteligibilidade, que se coloca num nível diferente e mais profundo. A própria estrutura da ciência moderna é caracterizada, com efeito, por uma estreita sinergia entre a experiência e a matemática: é esta a chave dos resultados gigantescos e sempre crescentes que se obtêm através das tecnologias, que agem sobre a natureza e colocam a nosso serviço suas imensas energias. A matemática nos impele, porém, para além de tudo o que podemos imaginar e representar sensivelmente e, exatamente deste modo, permite 
chegar aos mais extraordinários resultados cognoscitivos e operativos, por exemplo com as equações da mecânica quântica e da teoria da relatividade. De outro lado, as avaliações experimentais das previsões científicas e o sucesso de suas aplicações práticas confirmam que existe uma correspondência profunda entre a natureza e este nosso conhecimento empírico-racional (e não somente empírico): é neste sentido que afirmamos que o universo é inteligível. Trata-se de uma inteligibilidade intrínseca à natureza e não a ela externa, uma vez que é a própria natureza a ser, ao menos de certo modo, cientificamente cognoscível. Contudo, não pode ser uma inteligibilidade de que a natureza seja dotada por si mesma e de maneira autônoma: seria, de fato, totalmente injustificada e por fim absurda uma inteligibilidade que existisse por si mesma, sem ser fruto e expressão de uma inteligência. Somos levados, portanto, a admitir uma inteligência originária, que seja a fonte comum tanto da natureza quanto da nossa racionalidade: uma inteligência distinta e transcendente em relação à natureza, mas, contudo, ao mesmo tempo, presente a ela de maneira tão íntima e constitutiva que faz existir uma natureza em si mesma inteligível (delineei esta trajetória no pequeno livro Le ragioni della fede. Indicazioni di percorso, ed. Paoline 1993. Devo os ulteriores esclarecimentos aqui propostos a J. Ratzinger-Benedetto XVI, Fede Verità Tolleranza. Il cristianesimo e le religioni del mondo, ed. Cantagalli 2003, pp.188-192; encontro com os jovens de Roma e do Lácio, 8 de abril de 2006; discurso na Universidade de Regensburg, 12 de setembro de 2006).

No que tange a esta segunda trajetória para a existência de Deus, parecem necessárias algumas especificações. Esta trajetória parece particularmente adaptada à situação cultural hodierna, na qual as ciências e os homens de ciência têm um papel extremamente grande. Tem, além disso, a vantagem de pôr em discussão - em certo sentido "a partir de dentro" - aquela tendência a considerar o conhecimento científico como o único capaz de nos fazer conhecer algo de racional e válido para todos, que frequentemente desemboca na negação da possibilidade de conhecer a Deus e ainda na redução do sujeito humano a um objeto entre outros. Deve ser dito claramente, porém, que também esta trajetória para Deus, embora valorizando a estrutura da ciência empírica, não se coloca no plano deste gênero de ciência e nem tampouco da epistemologia entendida como estudo dos métodos e da índole próprios do conhecimento científico, mas se desenvolve, ao contrário, em nível filosófico e mais precisamente metafísico, como reflexão sobre as condições ontológicas que tornam possível o conhecimento científico. 
As objeções que são levantadas contra uma tal trajetória dizem respeito principalmente ao fato mesmo que a natureza seja por nós inteligível. Continua clássica a este propósito e exerce ainda uma grande influência a tese de Kant, que já criticamos, segundo a qual as ciências fariam conhecer não a realidade, mas somente o "objeto". Hoje, porém, as objeções apelam sobretudo àquelas correntes da epistemologia que sublinham os limites do conhecimento científico, em particular sua característica de ser passível de revisão e seu caráter provisório, de modo muito diferente daquilo que se pensava no tempo de Kant. Conhecimento passível de revisão e provisório não equivale, porém, a nenhum conhecimento: em concreto, nenhuma crítica epistemológica nos deve levar a colocar entre parênteses aquela capacidade de penetração na natureza que, por mais que seja parcial, sujeita a revisão e imperfeita, permite às ciências não limitar-se a descrever os fenômenos diretamente observáveis, mas sim indagar deles, para tirar conclusões acerca de outros fenômenos, dos quais se obtém frequentemente controle experimental, além de conseguir, mediante as tecnologias, crescentes resultados práticos.

O princípio de indeterminação da mecânica quântica, com a conseqüência que determinadas leis são somente estatísticas e probabilísticas, não impede que também estas leis constituam uma forma de conhecimento intelectual dos fenômenos físicos, embora muito diferente daquela das leis da mecânica clássica. Tais leis implicam, de fato, por sua vez, séries muito complexas de processos lógicos, através dos quais se tornou possível uma nova penetração no mundo físico.

Deve-se tomar em atenta consideração, além disso, a existência de uma grande abundância de sistemas físicos caóticos, que nossos instrumentos matemáticos atuais têm muita dificuldade de dominar. Isto mostra que a natureza não poder ser - ao menos por agora - totalmente representada através de uma abordagem matemática; não implica, porém, de nenhum modo, que aqueles sistemas sejam própria e absolutamente ininteligíveis. É claro, além disso, que não todo o universo é caótico, já que as previsões científicas encontram múltiplas verificações e nossas tecnologias funcionam.

Este itinerário para a existência de Deus a partir da inteligibilidade da natureza é certamente próximo da "quinta via" de São Tomás (enquanto o itinerário precedente corresponde de algum modo às primeiras quatro "vias"). Diferentemente dela, porém, não parte da presença da finalidade no universo, mas, de maneira mais global e radical, da constatação de que o universo é inteligível. 
Ao procurar chegar à existência de Deus partindo do nosso conhecimento humano da natureza, não me referi aos aportes que poderiam ser fornecidos pelos resultados, e não só pela estrutura, dos atuais conhecimentos científicos seja do universo seja, em particular, da vida. Os motivos desta escolha são principalmente dois: o contínuo evolver de tais conhecimentos, que torna precárias as conclusões baseadas sobre eles, e a necessidade, em todo caso, de uma passagem não "física", mas metafísica, se com nossa razão queremos realmente chegar, embora imperfeitamente, a Deus. Isto não significa, porém, que a imagem do universo e da vida atualmente proposta pelas ciências não seja de grandíssimo interesse para a abordagem racional de Deus (como de resto, em todos os tempos, a abordagem de Deus foi condicionada pela imagem do universo então vigente). Limito-me a observar que a concepção, que hoje se afirma no mundo científico, do universo como "história" que evolve não é certamente menos compatível, mas, antes, muito mais em sintonia com a contingência do universo - ou seja, com a sua não auto-suficiência ontológica - se comparada à concepção precedente do próprio universo caracterizada somente pela perenidade das leis físicas.

De outro lado, os limites intrínsecos das ciências modernas, que derivam de sua estrutura e metodologia, e a nítida distinção, a ser mantida, entre saber científico e saber filosófico e metafísico, não implicam que deva ser ignorado aquele renovado interesse que as grandes perguntas sobre o homem, a vida, a totalidade do universo, suscitam sempre mais entre aqueles que se empenham na pesquisa científica. Com efeito, exatamente o avanço das ciências estimula a colocar problemas que excedem os cânones metodológicos das próprias ciências. Não freando, mas, ao contrário, encorajando este interesse, poderá progredir, na recíproca distinção, uma fecunda interação entre as ciências e a filosofia, e também entre as ciências e a teologia, com a mediação da filosofia.

\section{A via que parte da experiência ética}

A terceira trajetória racional para a existência de Deus refere-se ao bem e à nossa capacidade de amá-lo, acolhê-lo e realizá-lo. Como ponto de partida, tomemos o sujeito humano, em particular a existência em nós e a percepção do valor moral e da obrigação moral. Eles, de fato, constituem um dado irredutível da nossa consciência e experiência, dotado de uma incondicionalidade que não pode ser colocada totalmente em função de nenhum objetivo ou fim externo ao próprio valor moral, embora outros objetivos (por exemplo, a conservação 
de nossa espécie) possam certamente ligar-se ao valor e à obrigação moral. Uma total redução funcional faria, com efeito, com que a incondicionalidade do valor e da obrigação se esvaísse; e comportaria, portanto, a eliminação da experiência moral enquanto tal. $\mathrm{O}$ valor moral que está na base desta experiência refere-se certamente ao sujeito humano, à sua razão, vontade e liberdade, e a todas as condições e condicionamentos sociais e históricos nos quais o sujeito vive. Não pode, todavia, resolver-se integralmente neles, uma vez que isto equivaleria a tornar a experiência moral totalmente relativa ao sujeito e à sua história, suprimindo de novo seu caráter incondicionado. De outro lado, o valor moral não pode gozar nem mesmo de uma prioridade "em si”, que se refira, em última análise, somente ao próprio valor: também ele, com efeito, para valer efetivamente, tem necessidade de existir. A pessoa humana (e, com ela, a comunidade dos homens), com seu caráter de fim e com sua dignidade inviolável, pareceria poder representar para o valor um tal ancoramento na realidade: a um exame mais atento, porém, o valor propriamente moral da pessoa concreta passa através de sua adesão ao próprio valor, adesão a um tempo livre e obrigatória, e, portanto, não pode fundar este valor, mas, antes, o pressupõe. Fundamento adequado do valor moral, na sua incondicionalidade, pode ser, por conseguinte, somente um ser incondicionado que coincida com este valor: precisamente através desta coincidência se exprimem a existência e a natureza íntima de Deus.

Esta trajetória teria necessidade, certamente, de uma formulação e uma justificação mais amplas e aprofundadas (para as quais remeto à Ética geral, de J. de Finance, editada em 1975). Limitar-me-ei a algumas especificações que enquadram melhor a própria trajetória. Antes de mais nada, o valor e a obrigação moral encontram seu fundamento próximo não em Deus, mas na incondicionalidade a eles intrínseca. Não é possível, além disso, deduzir de Deus o valor e a obrigação moral, enquanto o próprio Deus não for reconhecido como "moral", embora num sentido totalmente transcendente (o Deus três vezes santo de Isaías 6,3, que é a agápe: cfr $1 J o$ 4,8.16). Precisamente enquanto é, desta maneira transcendente, "moral" em si mesmo, Deus é o fundamento último do valor moral e da obrigação: sem ele, estes existem, mas não podem ser justificados de modo plenamente coerente.

Dito isto, não é difícil identificar sejam os pontos de contato sejam as diferenças entre esta trajetória e o modo como Kant afirma a existência de Deus, sumamente santo e feliz, como terceiro postulado da razão prática. Aqui me importa somente sublinhar que, enquanto para Kant se trata 
exatamente de um "postulado" que permanece fora do âmbito da razão teorética e é afirmado só pela "fé" ou "conhecimento prático", em virtude da necessária conexão que deve existir entre a bondade moral e a obtenção da felicidade, a trajetória que propus examina certamente a experiência moral na sua irredutível especificidade, mas para refletir sobre suas implicações em termos não só éticos, mas sim metafísicos.

A trajetória racional para Deus a partir da experiência ética pode ser impostada também de modo a levar a Deus como àquele que nos dá a capacidade efetiva de agir moralmente, antes que como fundamento do valor e da obrigação moral. Trata-se de uma abordagem sem dúvida estimulante, mas que deve estar atenta ao risco de que a existência de Deus seja afirmada como uma exigência nossa e não, antes de tudo, como uma verdade que reconhecemos objetivamente válida. É verdade, aliás, que um risco deste gênero está sempre presente, de algum modo, em toda trajetória para Deus que parta da experiência ética. $\mathrm{O}$ problema aberto que deriva da existência do mal no mundo e especialmente no homem não pode deixar de ter, de resto, um impacto particularmente direto sobre toda trajetória racional para Deus que parta da experiência ética.

\section{Síntese e perspectivas}

\section{Retornando aos nossos passos}

Tentemos agora uma abordagem sintética e uma avaliação crítica das três trajetórias propostas. Elas se referem, como acenei antes de formulá-las, aos três transcendentais - o ser, a verdade, o bem - e cada um deles pode ser desenvolvido colocando em maior ou menor relevo o papel específico do sujeito "cognoscente", "volente", além de, obviamente, existente.

Não me referi a um quarto transcendental, o da beleza, mesmo se estou convencido de que a experiência da beleza seja uma via muito importante para ir a Deus. Penso, com efeito, que esta via se preste mais a abrir nosso ânimo a Deus do que a fornecer a base de uma trajetória racional para ele.

O Deus cuja existência estas trajetórias levam a reconhecer é, por sua vez, inseparavelmente, existente, inteligente e "volente", embora de um modo que transcende toda a nossa capacidade de conhecer. Usando termos que se encontram, por assim dizer, mais da parte do objeto, ele é o ser, a verdade, o bem originário. Ao chegar a afirmar sua existência, conseguimos, então, também precisar, ao menos de modo inicial, o que, ou melhor, quem ele é. 
De modo particular, dada a tendência a colocar como alternativas a bondade moral de Deus e sua onipotência, tendência que se reforçou especialmente depois das tragédias históricas do século XX, é importante precisar que onipotente e bom são os dois predicados que, exatamente na sua inseparabilidade, permitem uma primeira identificação do significado da palavra "Deus", distinguindo tal significado de tantas reduções e contrafações a que este nome pode estar sujeito.

Todas as três trajetórias, como disse, comportam uma passagem propriamente metafísica, portanto, não verificável mediante a experiência sensível. Esta é a condição para tentar aproximar-se da realidade transcendente de Deus, mas, em minha opinião, é também a fonte de um limite nunca eliminável que se aninha em toda trajetória racional para Deus. Acenou-se já aos limites do conhecimento científico, apesar de seu constante recurso à verificação experimental: seria estranho que a filosofia, e particularmente a metafísica, não tivessem limites não menos graves, mesmo se diferentes. Se me é lícito dar um passo adiante neste difícil terreno, diria que, de um lado, não obstante a irredutível multiplicidade de posições contrastantes que perpassa toda a história do pensamento filosófico - e que frequentemente é lembrada como um motivo para não dar crédito à filosofia como fonte de conhecimentos objetivamente válidos -, esta história é também caracterizada pela presença de algumas constantes, que, sendo embora, por sua vez, sujeitas a contestações antigas e novas, todavia são sempre vivas e convincentes. Um exemplo é a confutação dos antigos sofistas feita por Platão e Aristóteles e ainda hoje fundamental para responder a quem nega a própria possibilidade de conhecer a verdade, como procurei mostrar precedentemente. Na base desta persistência está, em minha opinião, uma "metafísica latente", presente e operante em todo conhecimento intelectual nosso, que a metafísica reflexiva deve tematizar e tornar explícita. De outro lado, a impossibilidade de verificações experimentais não permite imaginar, em âmbito propriamente filosófico, progressos resolutivos - ou também mudanças de paradigma - que permitam processos de acumulação de conhecimento análogos àqueles que constituem um dos méritos fundamentais das ciências modernas, apesar da sua falibilidade e provisoriedade.

Penso que, hoje, a metafísica deve levar a efeito uma auto-limitação e um rigor que ultrapassem nitidamente o que já foi realizado pelos grandes metafísicos da antiguidade e da idade média. Desse modo, deveria ser 
melhor salvaguardada, também do ponto de vista da metafísica, aquela absoluta transcendência de Deus quanto a toda capacidade da nossa mente, transcendência esta bem resumida nas palavras Deus semper maior.

As dificuldades da abordagem metafísica no contexto cultural contemporâneo, acrescentando-se ao problema constituído pela existência do mal no mundo, são as razões de fundo daquela "estranha penumbra que pesa sobre a questão das realidades eternas", para usar as palavras do então Cardeal Ratzinger (L'Europa di Benedetto nella crisi delle culture, cit., pp. 115-124). Por isso a existência do Deus pessoal, mesmo se pode ser solidamente argumentada, como procuramos fazer, não é objeto de uma demonstração apodíctica, mas permanece "a melhor hipótese ... que exige da nossa parte renunciar a uma posição de domínio e de arriscar-se à posição do escutar humilde".

\section{Deus e o "florescer do homem"}

Um tal reconhecimento, que confirma o que dissemos no início sobre a impossibilidade de uma abordagem puramente "neutral" e objetiva da questão de Deus, tem grandes implicações para as relações entre crentes e não crentes: já por esta razão de fundo, estas deveriam ser caracterizadas por um genuíno e decidido respeito recíproco, pelo "sincero e prudente diálogo" de que fala o Concílio Vaticano II (Gaudium et spes, 21). Desse modo é superada a acusação, dirigida ao monoteísmo, de ser fator de intolerância e de contraposição entre os homens.

Uma outra consequência muito relevante diz respeito à relação entre o conhecimento racional de Deus e a fé no Deus que se nos revela em Jesus Cristo. Entre eles continua certamente aquela diferença profunda e nunca eliminável que aprendemos ao estudar Teologia. Esta diferença torna-se, porém, de algum modo, menos radical do que julgava, por exemplo, São Tomás de Aquino, pois, também na abordagem racional de Deus, nossa livre vontade tem um papel essencial e, por conseguinte, grande é o espaço para a graça de Deus que nos atrai a si. Por isso a oração tem uma tarefa e um significado fundamental em toda a nossa relação com Deus: dele devemos suplicar o dom da fé, que nos dá aquela certeza incondicionada e ao mesmo tempo livre acerca de Deus, que, como explica São Tomás (Q. D. de Veritate, q. 14, a.1c; Summa Theologiae, II-II, q. 2, a.1c), não exclui o espaço para ulteriores investigações, mas sustenta nossa fidelidade a Deus até o dom de nós mesmos - o que nossa razão sozinha muito dificilmente poderia fazer -. 
Muitos são, porém, no atual contexto social e cultural, os obstáculos que encontramos no caminho da oração. Entre eles, lembro somente aquele que é, talvez, o menos explícito, mas o mais difundido e provavelmente o mais insidioso. O mundo da nossa experiência é sempre mais a obra do homem, da sua cultura e das suas tecnologias, e sempre menos o mundo da natureza que nos é dado independentemente de nós. Para encontrar neste mundo, obra de nossas mãos, a presença de Deus, não é mais suficiente, portanto, o maravilhamento diante da abóbada celeste. Torna-se muito importante a indicação, que já encontramos em São Tomás (Q. D. de Veritate, q. 6, a.2c), de uma "via media" entre as duas posições que já se confrontavam em seu tempo: a "aristotélica", que remetia os fenômenos do mundo às suas causas intramundanas, e a "religiosa", que os remetia diretamente a Deus. São Tomás supera o contraste entre as duas posições e mostra, ao contrário, sua complementaridade: isto é, os fenômenos do mundo têm suas causas imanentes, a serem indagadas com método racional; mas têm também, todos juntos, sua raiz última na ação criadora de Deus, que diz respeito não só à origem, mas à existência inteira e ao vir a ser do universo e do homem nele. Hoje, quando a ciência não é mais a de Aristóteles, mas uma ciência capaz de transformar nossa vida e o mundo, a indicação fornecida por São Tomás - e substancialmente retomada e desenvolvida pelo Concílio Vaticano II (Gaudium et spes, 36-37) - tornou-se, em minha opinião, um percurso obrigatório para uma oração que não prescinda da nossa experiência quotidiana e não entre em contraste com ela, mas, ao contrário, possa iluminar e sustentar a nossa vida, tal como ela concretamente se realiza.

Gostaria de terminar retomando a sugestão de Ch. Tayor, que nos convida a pôr a abertura para Deus em conexão com o "florescer do homem". Existe um profundo paralelismo entre o aproximarmo-nos de Deus e o aproximarmo-nos de nós mesmos enquanto sujeitos inteligentes e livres. Em ambos os casos, estamos submetidos, no nosso tempo, à pressão de um forte e difundido cientificismo epistemológico e naturalismo materialista, que gostariam de declarar Deus inexistente ou, ao menos, racionalmente não cognoscível, e reduzir o homem a um objeto da natureza entre outros. Hoje, como talvez jamais precedentemente, torna-se claro, por conseguinte, que a afirmação do homem como sujeito e a afirmação de Deus simul stant et simul cadunt, juntas subsistem e juntas caem. Isto, de resto, é profundamente lógico, já que, de um lado, é bastante difícil fundar um verdadeiro e irredutível emergir do homem frente ao resto da natureza se a própria natureza é a única realidade; e, de outro lado, é igualmente difícil deixar racionalmente aberta a via para o Deus pessoal, inteligente e livre - de 
modo verdadeiro mesmo se transcendente - se não se reconhece antes de tudo, ao sujeito humano, este irredutível caráter pessoal.

Mostramos, assim, que Deus é o pressuposto indispensável do "florescer do homem" do ponto de vista do ser e, portanto, da metafísica. Mas é da mesma forma indispensável, sob um aspecto mais histórico, existencial e concreto, em relação ao nosso tempo e à pastoral da Igreja, além de em relação à teologia.

Uma primeira consideração a este propósito diz respeito àquele desejo de afirmarmo-nos a nós mesmos, àquela "mudança antropológica", mediante a qual, na época moderna, o homem, o sujeito humano, colocou-se no centro da realidade. Esta mudança desenvolveu-se historicamente como "emancipação" (cfr as conferências de Mons. Romera), antes de mais nada, frente a Deus: da "autonomia" da razão e da moral segundo Kant, à negação do Deus dos "humanismos ateus". Atualmente, porém, a fim de se poder manter de pé e prosseguir na história, a mudança em direção ao sujeito tem necessidade de Deus. Isto emerge precisamente da crítica da "pós-modernidade" à modernidade e à sua pretensão de auto-suficiência do sujeito humano. Emblemática é, no que tange a este ponto, a afirmação com que J.-P. Sartre conclui seu livro $O$ ser e o nada: "O homem é uma paixão inútil". Neste contexto cultural e espiritual, João Paulo II, na Encíclica Dives in misericordia, 1, sublinhou com grande força que o antropocentrismo e o teocentrismo não são de modo algum contrapostos entre si, como frequentemente se pensou e se continua a pensar, mas, ao contrário, estão unidos na história do homem de modo orgânico e profundo. Ele considera isto como o princípio talvez mais importante do magistério do Concílio Vaticano II.

Com efeito, se Deus não existe e, portanto o homem - todo indivíduo e o gênero humano todo - está só no universo, simplesmente vem da natureza e volta à natureza (uma natureza que não sabe nada acerca dele e que dele não cuida, como não sabe nada de si mesma e não cuida de si mesma nem de nada que nela nasça), é difícil pensar que nos seja possível satisfazer, de alguma forma, aquele "anseio de plenitude" que se encontra inserido no nosso ser e, portanto, em cada um de nós, e não permanecer, ao contrário, totalmente prisioneiros daquele sentido de nossa finitude que é, também ele, constitutivo de nosso ser. Considerações deste tipo podem representar a base de trajetórias para a existência de Deus de tipo ético e existencial, muito adequadas à atual situação histórica e humanamente envolventes, mais do que possa ser o que propusemos como nossa "terceira via". Naturalmente, também estas trajetórias não devem permanecer na perspectiva do "como se" ("como seria belo para nós que Deus existisse"), mas devem conseguir realizar, a partir de suas premissas existenciais, a passagem 
"metafísica", que pode levar a afirmar a existência de Deus. Isto é, trata-se, aqui como em todos os outros casos, de mostrar que nossa razão, para ser totalmente coerente consigo mesma, deve reconhecer que Deus existe.

Uma segunda consideração refere-se ao que observou J. Habermas no que tange a culpa, redenção e salvação, conceitos fundamentais que parecem ter desaparecido do atual horizonte cultural. Aqui, como de resto já na consideração precedente, a resposta a um tal desaparecimento está na redescoberta não simplesmente de um Deus como ser absoluto e como mistério inexprimível, mas do Deus bíblico e cristão, que em Jesus Cristo nos mostrou a sua face, face de Pai e de amigo, e nos disse seu sim definitivo (2Cor 1,19-20). Na realidade, trata-se de uma revolução humanamente imprevisível no conceito de Deus, que é "sinal" do caráter realmente divino d'Aquele que - na antiga e, definitivamente, na nova aliança - se revelou a nós. É muito interessante, quanto a este ponto, ainda a concepção de "bode expiatório" proposta por R. Girard.

Uma terceira e última consideração diz respeito à força do amor e do perdão, que a fé no Deus de Jesus Cristo introduz nos nossos corações e, portanto, também na história, apesar de todas as nossas contradições e infidelidades. No fundo, o que se censura principalmente à Igreja e ao cristianismo é de não serem coerentes consigo mesmos, antes de tudo do ponto de vista do amor e do perdão: deste modo, porém, acaba-se por reconhecer - de maneira implícita e involuntária, mas real - que, no cristianismo realmente vivido, o homem "floresce" de um modo único.

Testemunhar o verdadeiro Deus e, ao mesmo tempo, a verdade do homem é, por conseguinte, a grande tarefa que nos espera. Para realizá-lo, não devemos "mitigar" a densidade do ensinamento cristão sobre Deus e sobre o homem, rebaixando-o ao nível das modas culturais hoje propagadas e tornando-o, assim, insignificante. Ao contrário, somos chamados a propor, na linguagem do nosso tempo, mas, antes de tudo, na linguagem própria do cristianismo (que é, inseparavelmente, a linguagem do amor ao próximo e do testemunho do Deus vivo), toda a substância e beleza do próprio cristianismo.

\section{Referências Bibliográficas}

ASSMANN, J., Mosè l'egizio: decifrazione di uma traccia di memória. Adelphi, Milano 2007.

BENEDETTO XVI, Deus Caritas est. Libreria Editrice Vaticana, Città del Vaticano 2008. 
., Fede, verità, tolleranza: il cristianesimo e le religione del mondo. Cantagalli, Siena 2003. ., Il Dio della fede e il Dio dei filosofi. Un contributo al problema della theologia naturaris. Marcianum press 2007.

CHARLES, T., A Secular Age. Havard University Press, London 2007.

DUNN, J. D. G., Gli albori del cristianesimo. La memoria di Gesù.Paideia, Brescia 2006.

FINANCE, J., Etica generale. PUG, Roma 1997.

GIOVANNI PAOLO II., Dives in misericordia, n.1.

KANT, I., Critica della ragione pura. Adelphi, Milano 1999.

LAFONT, G., Dieu, le temps et l'être. Du Cerf, Paris 1986.

RATZINGER, J., L'Europa di Benedetto nella crisi delle culture.Cantagalli, Siena 2005.

RUINI, C., Le ragioni della fede. Indicazioni di percorso. San Paolo, Milano 1993.

SARTRE, J. P., L'essere e il nulla: saggio di ontologia fenomelogica. Saggiatore, Milano 1980.

THOMAS AQUINAS, Summa Theologica: editio altera romana. Forzani Desclée, Roma 1927-1928 (I, q.2, a.1.; II-II, q.2, a.1c.; Q. D. de Veritate, q. 14, a.1c.).

Catechismo della Chiesa Cattolica. Libreria Editrice Vaticana, Città del Vaticano 1992.

CONCILIO VATICANO I, Costituizione Dogmatica Dei Filius: in Denzinger

- Hünermann, Enchiridion Symbolorum. Barcelona, 2000: nn. 30003045 .

CONCILIO VATICANO II, Constituição Dogmática Dei Verbum: in Denzinger - Hünermann, Enchiridion Symbolorum. Barcelona, 2000: nn. 4201-4235.

CONCILIO VATICANO II, Constituição Dogmática Gaudium et Spes: in Denzinger - Hünermann, Enchiridion Symbolorum. Barcelona, 2000: nn. 4301-4345.

Camillo Ruini

Vigário Geral Emérito do Papa Bento XVI para a Arquidiocese de Roma

Artigo Recebido em 12/03/2011

Artigo Aprovado em 30/06/2011 